\title{
MONITORING OF AMMONIA IN ROSETTA BRANCH
}

Abd El-Razek, T. M. A. ${ }^{(1)}$; Abdullah, N. A. ${ }^{(2)}$ and Abdelmawla, M. A. ${ }^{(3)}$ 1) Institute for Environmental Studies and Research, Ain Shams University 2 Egyptian Company for Aluminum Sulfate 3) Egyptian Holding Company for Water and Wastewater.

\begin{abstract}
Rosetta branch is a source of fresh water for domestic, agriculture, industry, fisheries and recreation purposes for some western Delta governorates in Egypt. Unfortunately this branch is impacted by increasing concentrations of ammonia resulted from the agricultural drains located along its sides and by the industrial effluents of industrial activities and fish farming cages. This study aims at monitoring ammonia, dissolved oxygen nitrite and nitrate concentration along the Rosetta branch. Samples were taken at an interval of $5 \mathrm{Km}$ of the branch. Ammonia concentrations measured by a colorimetric Nessler method. Recorded ammonia ranged from 0.16 to 7.87 $\mathrm{mg} / \mathrm{l}$. Level of ammonia in Rosetta branch is very high after mixing with Rahawy drain, as it reached $6.77 \mathrm{mg} / \mathrm{l}$ and decreased gradually along the Rosetta branch to the lowest level of $1.67 \mathrm{mg} / \mathrm{l}$ at Kafr Yaqob village due to dilution along the branch and increased again, due to presence of fish cages along Gharbiya, Kafrelsheikh and Behaira governorate.

Key Words: ammonia, Rosetta branch, fish farming cages, Rahawy drain.
\end{abstract}

\section{INTRODUCTION}

Water needs increased as a result of population growth, industrial development and cultivation of desert land. Egypt relies for more than 90 percent of the water supply on the Nile River. Groundwater resources are non-renewable and rainwater is neglected, with the exception of the Mediterranean coastal area. Irrigated agriculture is by far the largest consumer of water (nearly 90 percent), and despite the progress in the field of 
irrigation and agricultural techniques stimulate water conservation, and the development of more crop intensification tables and expansion of agricultural areas increased demand for scarce water resources originally. Competing demands between industrial development and human consumption are a severe strain on a balanced distribution of limited resources to different users (Adelwahaab and Badawy, 2004).

Nile River travels along Egypt about 950 kilometers starting from upstream High Dam in Aswan, where it is divided in two branches at Khairia Barrage to Damietta and Rosetta each one runs separately for discharged into the Mediterranean sea. Rosetta branch travels about 239 kilometers and is the main source of fresh water to the provinces in the western direction to the Nile Delta (Zaghloul and Elwan, 2011).

Rosetta branch has an average width of about 180 meters and a depth ranges 2-4 meters. It ends at Edfina Barrage, located at 30 kilometers south of the sea to discharge of excess water to the Mediterranean. It is estimated that the aquatic environment of this branch receives more than 3 million $\mathrm{m}^{3} /$ day of untreated or partially sewage treatment of municipal wastewater and industrial effluents as well as agricultural drainage water (El Gammal and El Shazely, 2008).

Egypt Challenges a rapidly increasing deterioration in surface and ground water quality as a result of increased municipal wastewater and industrial effluents in waterways. Excessive use of pesticides and fertilizers, especially internationally banned and national illegal in agriculture is causing environmental risks (Ali et al, 2011). 
Industrial activity in Egypt consumes about 638 million cubic meters of water per year, of which 549 million cubic meters per year are discarded in public sewer systems. Greater Cairo region and Alexandria province holds about $40 \%$ of this amount. Industrial facilities rely about $65 \%$ of this amount of Nile water. The Nile River receives more than $57 \%$ of the effluent for these factories. (Ezzat, 2002).

Rosetta branch receives water of a number of agricultural drains, which are heavily polluted by industrial and domestic sewage. The drains receive alot of the wastewater from Greater Cairo region. The wastes in the drains contain high levels of suspended and dissolved solids, oil, grease, nutrients, pesticides and organic matters. It is suspected that toxic substances are present as well. (Adelwahaab and Badawy, 2004).

Rosetta branch is impacted by the agricultural drains located along its sides and by the industrial effluents coming from industrial activities in Kafrelzayat city. The drains are Rahawy, Sabal, Tahreer, Zaweit El-Bahr and Tala. These agricultural drains receive municipals waste water from 55 towns and villages located along the branch. Industrial effluents from pesticides, fertilizers and natural Salt factories are discharging directly into the east side of the branch (Donia, 2005).

Fish farming is very important in Egypt to meet the necessary needs for protein as well as it a simple system, it does not need additional water, economically feasible. There are many floating fish legal and illegal cages in accordance with national law in Egypt, where the prevention of Law No. 48 /1982 the use of the Nile River in fish farming, However there are mafia fish 
farming in Rosetta Branch challenge the law by floating cages has been established in freshwater bodies (Zaghloul and Elwan, 2011).

The Law No. 124/1983 manages fishing, fish farming and the aquaculture. The General Authority for Fish Resources Development of the Ministry of Agriculture is responsible for the implementation of this law which prohibits the use of Nile streams in fish farming (Ali et al, 2006).

Generally, intensive fish farming produces considerable amounts of nutrient waste such as ammonia, nitrates and phosphorus. These wastes deteriorate the nature of water body. Also, fish heavily consume the dissolved oxygen leading to low dissolved oxygen content in water.

It was reported that the environmental impact of fish-farming depends very much on fish species, culture method, stocking density, feed type and hydrography of the site. Most of the phosphorus, carbon and nitrogen input into the fish culture system are through feed residuals, fish excretion and faeces production. The use of chemicals and the introduction of pathogens and new genetic strains have also raised environmental concerns. Carbon dioxide produced by fish respiration is unlikely to create adverse effect on the environment (FAO, 2005).

It worth mentioning that the total amount of BOD discharged to the River Nile by industrial plants equals 270 ton/day. This amount corresponds to the untreated discharge of wastewater from more than six million people. It can be concluded that these substances are discharged mainly from the industrial activities in the Greater Cairo region and in Delta (0.75 and 0.50 ton/day). The average concentration of heavy metals (HM) in the effluent is less than 5 
$\mu \mathrm{g} / \mathrm{L}$. These two sources of pollution potentially affect and deteriorate its quality of water (EPADP and DRI, 2008).

Ammonia is a chemical substance that is found in nature or made by humans. Average amount of ammonia manufactured by humans each year, almost equal to the amount produced by nature every year. However, when it turns out that the levels of ammonia may cause concern, it is likely that it was made either directly or indirectly by humans (ATSDR, 2006).

Unionized ammonia is actually toxic and its toxicity is depends on the salinity, temperature and $\mathrm{pH}$. Nitrates and nitrites are not significantly toxic to aquatic life except in the context of promoting the blooms of algae. A significant decrease in dissolved oxygen (DO), and an increase in the biological oxygen demand (BOD), nutrients (organic and inorganic nitrogen and phosphorus,), have been identified in the water column around fish farms (Wu, 1995).

Ammonia oxidized biologically to produce nitrite and nitrate under uncontrolled conditions. Presence of ammonia in water consumes a higher concentration of chlorine to get a free residual chlorine. Also It cause the chloramines formation weak in the disinfection process as well as the increase in the amount of chlorine with organic load possesses high risk forming of harmful substances such as trihalomethanes and haloacitic acids (THMs, HAAs) which increase the potential of cancer infection. Therefore, removal of ammonia from water is desirable (EPA, 1975).

Law No. 48 of 1982 was issued to protect the River Nile from pollution, the criteria set forth by law identified concentrations in River Nile. and 
identified the concentration of ammonia that don't exceed $0.5 \mathrm{mg}$ per liter while dissolved oxygen at least $5 \mathrm{mg}$ per liter.

The aim of this study is to assess the ammonia content along Rosetta branch and to investigate the possible causes for ammonia elevated concentration.

\section{MATERIALS AND METHODS}

\section{Study Area:}

The area of this study extends to about $200 \mathrm{~km}$ in Rosetta branch, starting from Ikhsas village up to Edfina Barrage (35 sites were chosen), and about 40 $\mathrm{km}$ in Mahmudiya Canal with starting from Nikla village to Siuof WTP (13 sites were chosen). Samples were collected from the middle of the waterway in each of the Rosetta branch and Mahmudiya Canal. That lies on them intakes of WTP for Gharbiya, Kafrelsheikh, Beheira and Alexandria potable and Sanitation companies suffering because of the resulting increase of ammonia concentrations, Figure (1).

Samples were collected at an interval of 5 kilometers with additional samples collected in case of pollution sources discharge either agricultural drain or industrial effluents. 


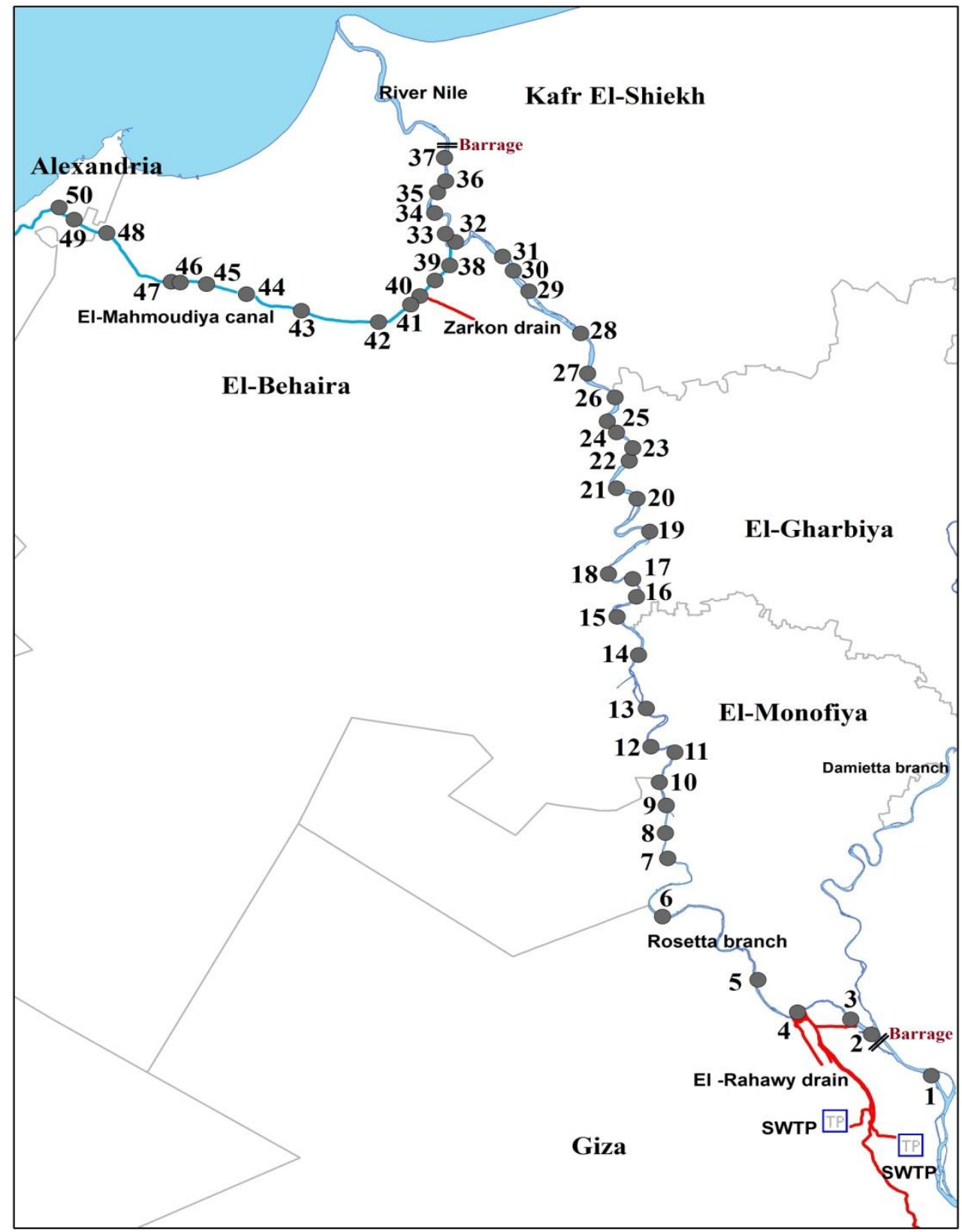

Figure (1): The selected sampling points. 


\section{Sampling Procedure:}

Water samples were collected in winter of 2013/2014 from Rosetta branch and Mahmudiya Canal. That increase the phenomenon of high concentrations of ammonia as a result of less water needs period to be determined by the Ministry of Water Resources and Irrigation identified from December until the first of March each year (in Egypt, Sadda Shetwia term). Water samples were collected (at depth of $50 \mathrm{~cm}$ from the surface) in stoppered polyethylene plastic bottles. All samples collected for either physical and chemical examinations were stored in an ice box and delivered immediately to the laboratory for analyses.

3. Materials:The used chemicals were of analytical grade.

\section{Procedures:}

Physical and chemical analyses were carried out according to Standard Methods for Examination of Water and Wastewater (APHA, 2005). Field parameters (temperature, $\mathrm{pH}$, electric conductivity (EC), dissolved oxygen (DO) and total dissolved solids (TDS) were measured on-site using portable multi parameter equepment (Model: HACH HQ40d multi)), ammonia, nitrite and nitrate were carried out by a colorimetric nesslerization method and the chloride was done by argentometeric method.

\section{RESULTS AND DISCUSSIONS}

Physical and chemical analyses of water samples collected from Mahmudiya Canal and Rosetta branch during winter 2013/2014 were presented in Table (1). 
Table (1): Some parameter of the water quality of Mahmodiya Canal and Rosetta branch during winter 2013/2014:

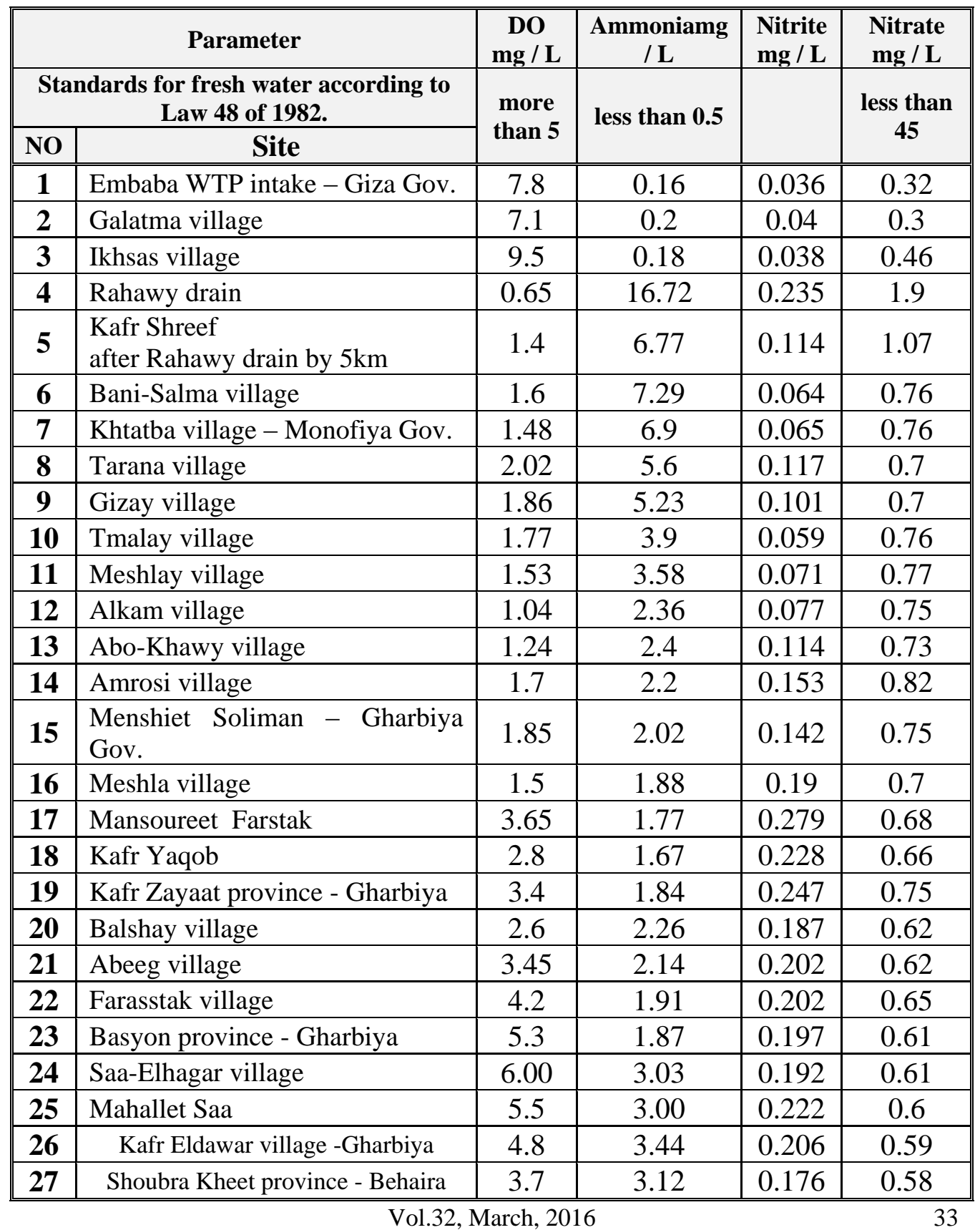


J. Environ. Sci.

Institute of Environmental Studies and Research - Ain Shams University

Table (1): Some parameter of the water quality of Mahmodiya Canal and Rosetta branch during winter 2013/2014 (cont'd):

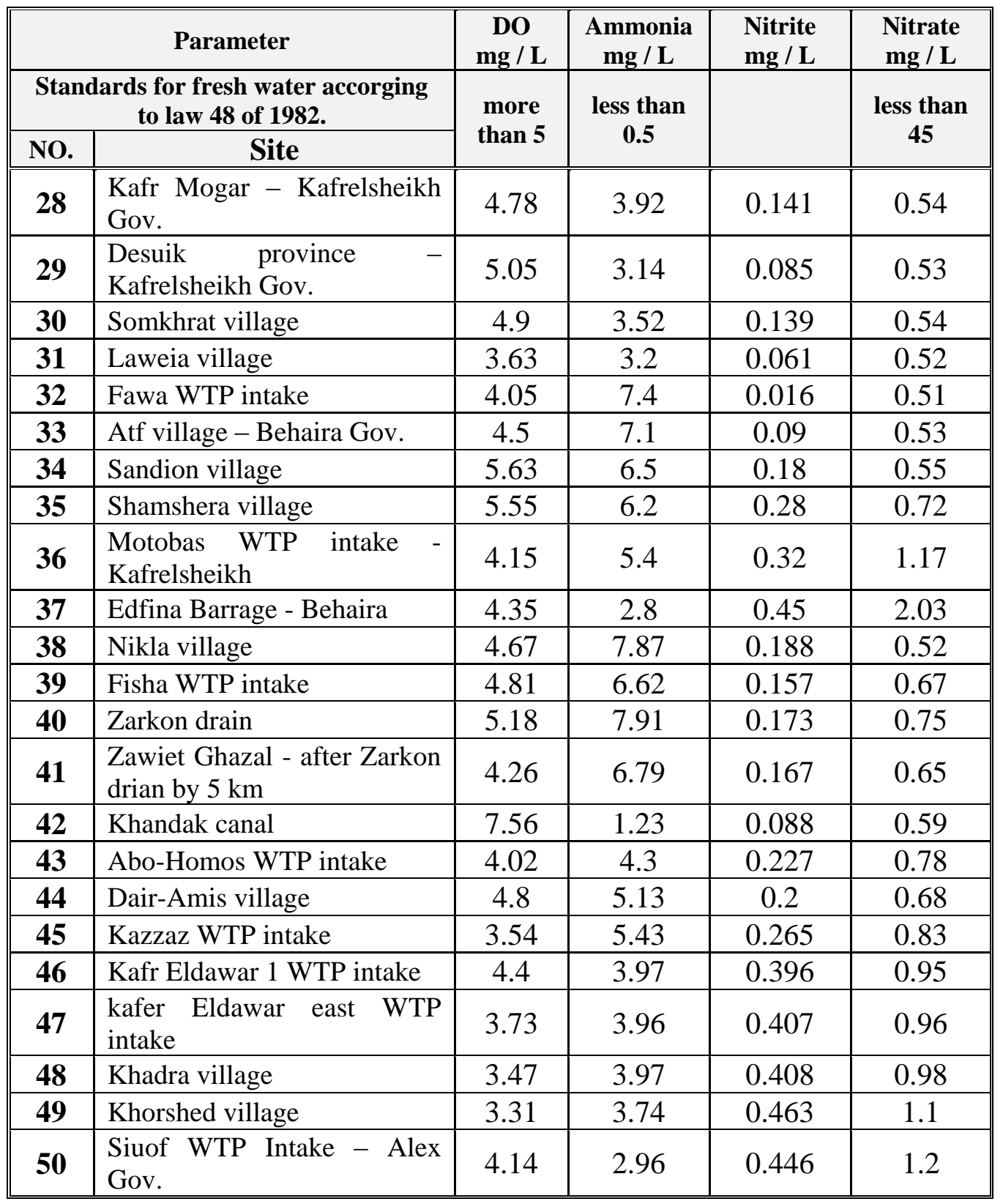


From the above results it is clear that the sample No. 3 at Ikhsas village refer to the natural water quality of Nile River and complat with the Law No. 48/1982, Then after mixing with Rahawy Drain, the values increase indicating the presence of pollution. Especially, DO measurements changed from 9.5 into $1.4 \mathrm{mg} / \mathrm{l}$, which refers to consumption of Oxygen duo to loads resulted from the discharge from Rahawy Drain. Also, the increase of nitrates indicates the presence of sanitary drainage.

The level of DO in Rosetta branch is very low after mixing with Rahawy drain (Sample No. 5; $1.4 \mathrm{mg} / \mathrm{l}$ ), (Figure 2). But It increases gradually along the Rosetta to reach highest level at Saa al Hagar village (Sample No. 24; 6 $\mathrm{mg} / \mathrm{l}$ ) due to aeration along the branch and then decreases again due to presence of fish cages along Gharbiya governorate and Kafrelsheikh governorate.

Results also show that the level of dissolved oxygen in Khandak canal is at a maximum value (Sample No. $42 ; 7.56 \mathrm{mg} / \mathrm{l}$ ), which is predictable result due to no source of contamination along this canal and also the level of ammonia is at a minimum $(1.23 \mathrm{mg} / \mathrm{l})$. The minimum level of DO is at Khorshed village (Sample No. 49; $3.31 \mathrm{mg} / \mathrm{l}$ ) may be due to narrowing of the canal.

From Table (1) The level of ammonia in Rosetta branch is very high after mixing with Rahawy drain (Sample No. 5; $6.77 \mathrm{mg} / \mathrm{l}$ ) and decreases gradually along the Rosetta branch to reach the lowest level (Sample No. 18; $1.67 \mathrm{mg} / \mathrm{l})$ at Kafr Yaqob village due to dilution along the branch and self water clean up. 
Ammonia increase again, due to the presence of fish cages along the Gharbiya and Kafrelsheikh governorate. many factors help to the harmful impact of fish farming in the Rosetta branch of which the storage density, type of feed, feed residue, fish production and excretion of feces. Carbon dioxide produced by the respiration of fish, which is likely to create a harmful impact on the environment.

The results show that the level of ammonia in Mahmudiya Canal reached maximum value at Nikla village (Sample No. 38 Equal $7.87 \mathrm{mg} / \mathrm{l}$ ), this means that the Zarkon drain (Sample No. 40) has a significant effect on Mahmudiya canal.

Nitrate concentrations are still within range, but the overall change in behavior illustrates the affect by increasing concentrations of ammonia, which consume a lot of dissolved oxygen. (Figure 2). 


\section{N. Forms and DO Concentration}

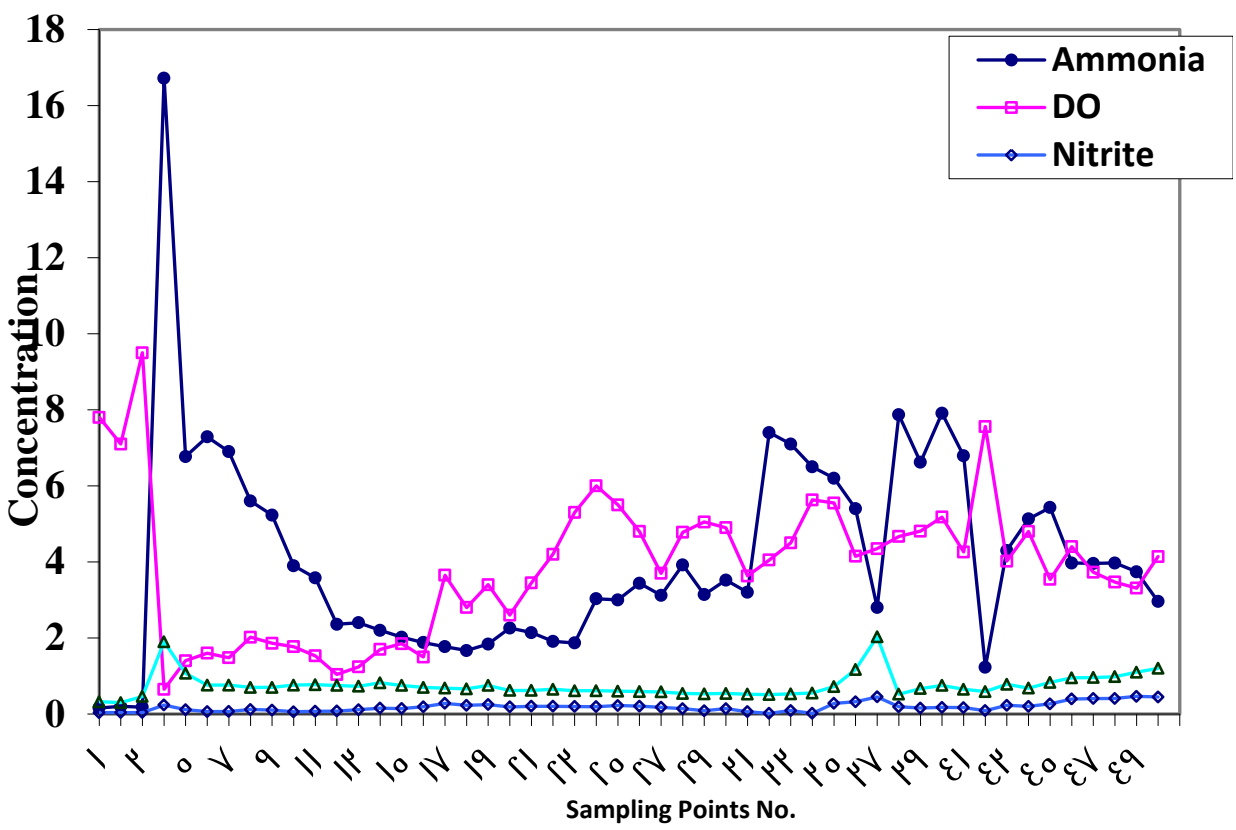

Figure (2): Level of ammonia along Rosetta branch and Mahmudiya canal

Previous interpretations show that Rosetta Branch and Mahmudiya canal used as a source of raw water in WTP intakes in Gharbiya, Kafrelsheikh and Behaira Governorates. Companies of water and wastewater in these Governorates face a lot of challenges and difficulties for the production of drinking water compliant with healthy standards mentioned in the decision No. 458/2007 Issued from the Ministy of Health, Especially at winter season (Sadda Shetwia from December into March each years) where water resources became heavily polluted due to lack of water. 
J. Environ. Sci.

Institute of Environmental Studies and Research - Ain Shams University

\section{CONCLUSION}

Although the law 48 of 1982 addresses the protection of the Nile River from pollution with mentioning of the permissible limits of water quality parameters, the recorded concentrations of ammonia were higher than the normal concentration in Nile River, so the water treatment plants consume chlorine demand.

Although mixing the Rosetta branch with Rahawy drain may cause an increase in ammonia concentration in the water, but the Rosetta branch fish cages play a significant role in this issue especially in Kafrelsheikh, as well as the violation of the law and impact of Gharbiya, Kafrelshiekh and Behaira governorate. Therefore the law must be enforced and the fish cages must be removed.

To achieve effective disinfectant we must add excess chlorine to get free residual chlorine. The strategy of the study is to remove or reduce the ammonia in raw water to avoid the negative impacts on the water quality during treatment.

\section{REFERENCES}

Abdelwahaab, R. and Badawy, I. M. (2004), “Water Quality Assessment of the River Nile System": An overview, Biomed Environment Sciences, 17, 87-100.

Agency for Toxic Substances and Disease Registry (ATSDR), (2004), Toxicological profile for Ammonia. Atlanta, GA: U.S. Department of Health and Human Services, Public Health Service. 
Ali, M.; Abdel-Meguid, M. and Abdin, A. (2006), Assessment of floating fish cages impacts on the water, fauna, flora, sediments, aquatic weeds, fish and hydraulics of Damieta branch, Scientific Bulletin, Faculty of Engineering, Helwan University, April, 2006.

Ali, S. M.; Sabae, S. Z.; Fayez, M.; Monib, M.; and Hegazi, N. A. , (2011), The influence of agro-industrial effluents on River Nile pollution. $\mathrm{J}$ of Advanced research, (2): 85-95.

American Public Health Association (APHA), ( 2005), Standard Methods for the Examination of Water and Wastewater, 21 Ed. Washington, D.C.

Donia, N. (2005), Rosetta Branch Waste Load Allocation Model. 19th International Water Technology Conference, Sharm El-Sheikh, Egypt, pp: 277-288 .

Egyptian public Authority for Drainage Projects (EPADP) and Drainage Research Institute (DRI), (2008), National Water Quality and Availability Management NAWQAM, component 3000 final technical report, National Water Research Center 'NWRC', and The Prairie Farm Rehabilitation Administration "PFRA".

El Gammal, H. A. and El Shazely H. S., (2008), Water Quality Management Scenarios in Rosetta River Nile branch, Egypt. 12th International Water Technology Conference, Alex., Egypt, pp: 901-912.

US Environmental Protection Agency (EPA), (1975), Process design manual for nitrogen control. U.S.EPA, Technology Transfer.

Ezzat, S. M., (2002): Microbial Flora and Chemical Composition of River Nile Water at Different Sites in Egypt. M.Sc. Thesis, Microbiology Dept., Fac. of Sci., Ain Shams Univ., Egypt.

Food and Agriculture Organization of the United Nations (FAO), (2005), Aquaculture production, 2003, Year book of Fishery Statistics Vol.96/2. Food and Agriculture organization of the United Nations, Rome, Italy.

Wu, J. (1995): Biodiversity and Landscapes: A Paradox of Humanity (Book Review), Journal of Environmental Quality 24(3):554-556. 
Zaghloul, S. and Elwan H., (2011), "Water Quality Deterioration of Middle Nile Delta Due to Urbanization Expansion, Egypt". 15th International Water Technology Conference, Alex., Egypt.

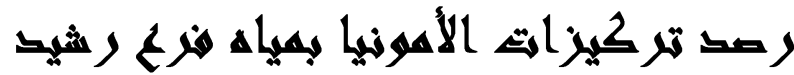

$[r]$

طه عبد العظيم محمد عبد الرازق(')- نبيل أحمد محمد عبد الله الصغير(r)

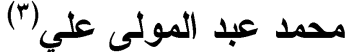

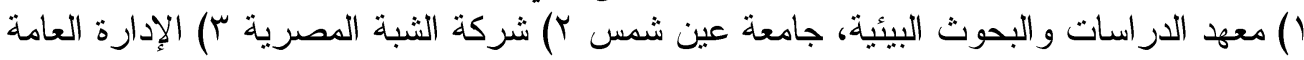
للجودة وشئون البيئة، الثركة المصرية القابضة لمياه الثرب و الصرفة الصدئ الصحي

\section{المستخلص}

فرع رشيد هو المصدر الرئيسي للمياه العذبة للمحافظات الواقعة على الجانب الغربي من دلتا

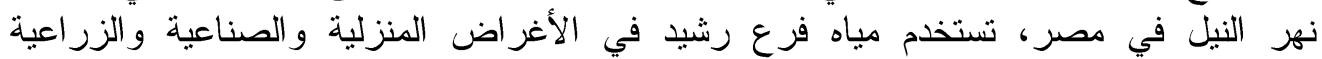

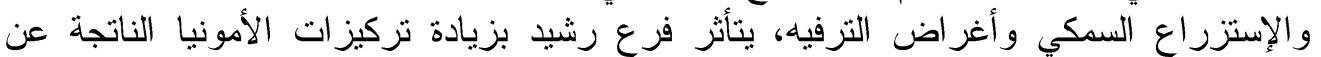

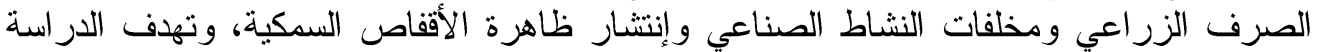

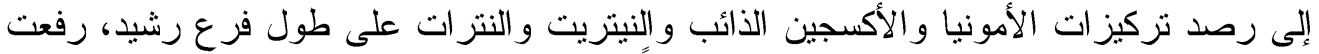

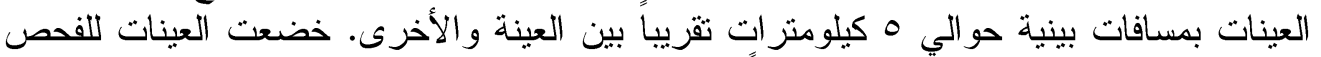

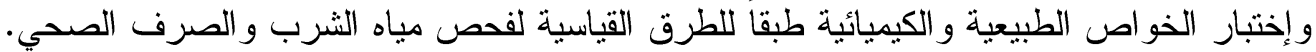

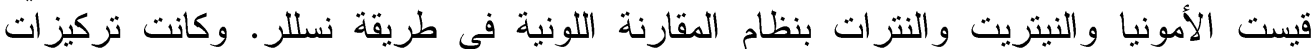

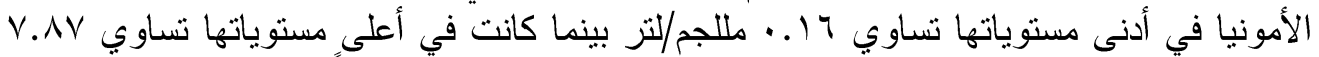

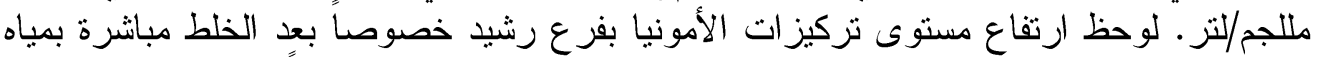

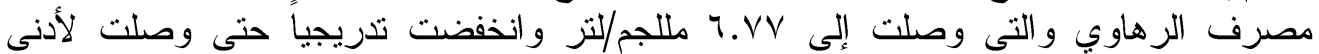

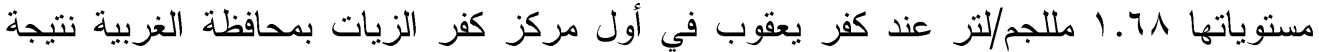

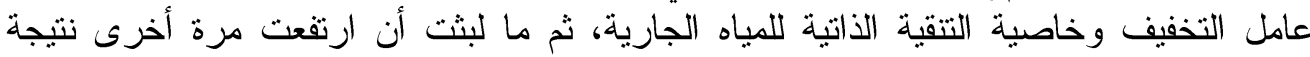
ظهور ظاهرة انتشار الأقفاص السمكية بمحافظات الغربية وكفر الثيخ. 